\title{
Consumer Credit other than for House Purchase Regulation in the Czech Republic and Selected EU Countries
}

\author{
Ivan SOUKAL ${ }^{1, *}$, Eva HAMPLOVA ${ }^{1}$, Anna CIERNIAK-EMERYCH ${ }^{2}$, Jiri HAVIGER ${ }^{1}$ and \\ Szymon DZIUBA ${ }^{2}$ \\ 1 University of Hradec Kralove, Hradec Kralove, Czech Republic; ivan.soukal@uhk.cz; eva.hamplova@uhk.cz; \\ jiri.haviger@uhk.cz \\ 2 Wroclaw University of Economics, Wroclaw, Poland; aemerych@wp.pl; dziuba@ue.wroc.pl \\ * Correspondence: ivan.soukal@uhk.cz
}

\begin{abstract}
A transposition of 2014/17/EU changed consumer credit markets throughout the EU. In the Czech Republic the transposition by the act 257/2016 Coll. was taken as an opportunity to unify regulatory framework for all consumer credit regardless of a purchase purpose. At the same time this regulatory framework extension was motivated by adverse phenomena in a non-bank consumer credit sector such as predatory and usurious practices (regulatory arbitration, abuse of the social distress of debtors, credit cost obfuscation, pre-contract payments, insufficient or even none creditworthiness assessment and more). These issues were addressed by the market entry public regulation including employee's professional qualification requirements. The paper compares professional qualification regulation approach in the Czech Republic and eleven selected EU countries. In the Czech Republic, Hungary, Greece was adopted the public regulation approach which combines national regulator supervisory with accredited institutions examination. On the other hand, in Germany and the Netherlands was an approach closer to a private regulation. Croatia and Portugal still did not completely transposed 2014/17/EU and are facing a legal procedure from the Court of Justice of the EU. In the Czech Republic a new regulation significantly decreased a number of non-bank consumer credit providers and their market share is diminishing since the last economic crisis. Yet, a new option of regulatory arbitrage for predatory creditors appeared although with a very limited impact on the market.
\end{abstract}

Keywords: consumer credit; regulation; Czech Republic; MCD

JEL Classification: G28; G23

\section{Introduction}

The financial sector is one of the most regulated sectors in an economy since it can be and was in the past a source of systematic economic failures that can lead to a global economic crisis. Retail credit provision is a fundamental service offered in this sector and therefore significantly regulated. Directive 2014/17/EU (European Parliament and Council, 2014) (frequently referred to as MCD) introduced several unifying concepts for EU economic area mortgage provision. Except for other features, it differed from previous consumer credit regulation because it also included the institutional component of regulation such as the market entrance. However, its transposition was in some countries with a greater range than just mortgage market and there were set rules applicable to any consumer credit including non-bank financial companies providing consumer credit other than for house purchase.

In general, there are two basic principles of consumer protection by EU consumer law information and fairness. However, MCD established two more principles of affordability and responsible lending (Méndez-Pinedo, 2015). Any non-bank credit provider is subjected to a duty to assess a consumer's creditworthiness. Explicitly it has to be done by reliable, sufficient and direct information provided by the consumer, and if necessary from a credit registers (bank, non-bank). 
There was also introduced standardization of pre-contractual information facilitates comparison (Rona-Tas and Guseva, 2013). In light of the last global financial crisis, neither of these two principles were respected. It is true that this concerns mostly other markets than Czech Republic, i.e. USA and in EU Mediterranean economies - foremostly Spain. Regardless of a territory, confidence in the financial sector had to restored or strengthened, ultimately leading to MCD.

However, in the Czech Republic, there were no trust issues with the bank sector unlike non-bank one due to three credit union bankruptcies in the last decade. Moreover, there were present adverse phenomena such as predatory and usurious practices in a non-bank consumer credit sector. These practices led to the more frequent seizure of property among mainly sub-average and low-income households. Czech parliament came to a conclusion to protect such vulnerable borrowers from predatory lending and also from making uninformed decisions that they will later regret. The situation with many borrowers unable to pay is both adverse for the industry and for the whole society. Achieving this goal without risk of fair competition and market balance negative interference was the main concern. However, the situation was a killing two birds with one stone scenario since unifying the regulatory framework for all types of consumer credit with MCD transposition would solve mentioned adverse phenomena. One of the regulatory rules was related to an issue of employees involved in the provision and intermediation of a consumer credit professional qualification. It is not uncommon that non-bank providers bear a lack of professional qualification as a competitive disadvantage compared to bank ones (Da Silva et al., 2017) but there were tens of thousands of credit providers as a tied sole trade suggesting a substantial share of unprofessional providers performing among other things predatory and usurious practices.

\section{Regulatory approaches in Non-bank Financial Market}

As any financial intermediation, non-bank consumer credit provision carries a systemic risk which creates the need for regulation. As (Anagnostopoulos, 2018) mentions concerning non-bank financial companies, any regulation density and policy options should be proportionate to: size, liability volumes, geographical expansion, scope, and business models.

A regulatory strategy of consumer credit provision is following general open-ended standards principles which are typical for EU legal environment. In such mandatory rules leave space for even private rule-making, giving rise to typical co-regulatory arrangements where public law-maker defines mandatory minimum standards or general principles, the private one specifies them or raise standards (Cafaggi, 2009). Therefore, there can be found several regulatory approaches that can be sorted accordingly the space for private rule-making.

Regulation is commonly viewed as affecting lender behavior by e.g. risk weightings, capital buffers (entity-based regulation) and by e.g. loan-to-value caps, debt-to-income ratios, interest coverage (borrower-dependent regulation) (Anagnostopoulos, 2018). The regulatory tools of proving a professional qualification of all employees involved in the provision and intermediation of a consumer credit belong into the entity-based category.

The Consumer Credit Directive and MCD are given by (Cherednychenko, 2016) as a good illustration of the involvement of private actors in standard-setting within the EU principles-based regulatory framework that implicitly leaves room for co-regulation can be found in the area of consumer credit. This directive allows Member States considerable leeway in implementing this obligation of EU origin in transposition.

Another possibility is for a public regulator to rely upon the senior management of financial institutions to put in place appropriate systems and oversight mechanisms. This management-based regulation stimulates modes of self-organisation within financial institutions so as to achieve certain public goals (Baldwin et al., 2010). However, this approach is present in other parts of the financial market such as investment firms where they define, approve and oversee a policy as to such products in accordance with the firms' risk tolerance (Cherednychenko, 2016).

The last option is a strictly public regulation that is proposed, set and performed by a national or specialized regulatory institution. However, completely neglecting an opinion private sector and their rightful interest may result in inefficient regulation ion terms of industry performance. Also, on a 
financial market, (Stringham, 2015) warns that a substitution of private regulation in the financial services field by hardcore public regulation and/or public soft law produced by regulators is not without risk. For example, too restrictive rules on responsible lending may prevent consumers from gaining credit from licensed creditors and force them to seek other less safe and more costly ways how to obtain a credit. Therefore, a possible inconsistency in regulatory concepts regarding sectors and products has to be considered since they raise the risk of regulatory arbitrage.

\section{Regulation Implementation}

\subsection{Czech Republic}

There were several reasons for a regulation extension from the range set by (European Parliament and Council, 2014). At first, inconsistent regulatory concepts regarding sectors and products raise both the risk of regulatory arbitrage and also cause additional costs for businesses to ensure compliance of their activities with individual and different regulatory environments. Consumers also incur the cost of learning about different rules for different products and sectors (learning costs). Inconsistent legislation may also complicate the effective exercise of integrated supervision. To be more specific, there were credit providers completely out of national regulator reach such as sole traders providing or intermediating consumer credit. Parliament and Ministry of Finance predatory and usurious practices in the non-bank lenders market are a very serious negative socio-economic phenomenon (Chamber of Deputies, 2014). Especially such practices included:

- too easy market entry causing lack of professional qualification

- regulatory arbitration with the artificially divided principal is several credits in order to remain below regulation requisite (being over $5.000 \mathrm{CZK}$ )

- abuse of the social distress of debtors when lender speculates on the debtor's default followed by strong contractual sanctions or pre-contract payments

- obscuring of credit cost

- insufficient or even none creditworthiness assessment

- predatory use of a bill of exchange in case of a default

From several proposals, such as APR ceilings, there was like the most appropriate solution chosen market entrance regulation by a national regulator. After consultation in parliament and at Ministry of Finance, Czech Republic received a positive opinion from European Central Bank (European Central Bank, 2015) stating that these sole traders were only lightly regulated and supervised by the Czech Trade Inspection Authority. This was the argument in favor of incorporating sole traders into the regulatory framework of the national regulator which was so far hesitating to accept such wide regulatory extension.

The regulatory framework was approved and set in act No. 257/2016 Coll. (Parliament of the Czech Republic, 2016) however, professional qualification requirements were further specified in following Czech National Bank regulatory decrees and supervisory benchmarks. Non-bank consumer credit providers have to state in their organization rules which functions are performed by employees and thus can be performed only by persons who meet the requirement of professional qualification by $\S 60$ of the Act of (Parliament of the Czech Republic, 2016), including the definition whether they are directly involved or responsible for it. Qualification requirements and examination process are set accordingly:

- accreditation for professional examinations organizing (Czech National Bank, 2016a)

- details of the essential elements of an application for authorization to pursue the business of nonbank consumer credit including professional qualification (Czech National Bank, 2016a)

- The manner of generating tests when organizing professional examinations, categories of qualification, types and number of test questions, score requirements, the scope of professional expertise and competence for the provision or intermediation of consumer credit (Czech National Bank, 2016b) 
- only an indirect relation mentioning the duty of managing and controlling the quality of intermediary distribution network internal regulations accordingly external and internal regulation (Czech National Bank, 2016b)

The national regulator provides a set of questions covering areas of:

- minimum expert knowledge of the financial market

- the structure, entities and functioning of the market for consumer credit other than for house purchase

- regulation of the market for consumer credit other than for house purchase

- lending and the products of consumer credit other than for house purchase

- complementary services related to consumer credit other than for house purchase

- the principles of the process for assessing a consumer's creditworthiness

Every single test is unique in terms of the order of the correct answers. The accredited institution examiner creates individual test variants on the day of the examination. Each test contains singleanswer questions, questions with more correct answers and case studies with sub-questions (Czech National Bank, 2017) The test has to be completed within two hours.

Professional qualification requirements are complemented by other rules related to improving the standard on the market. The national regulator imposed a general duty on creditors to assess whether the consumer is creditworthy before the conclusion of the credit agreement, so as to prevent consumer overindebtedness. These two capital requirements, firstly a market entry regulation which is based on minimal start level of capital of at least 20 million CZK (800,000 EUR). Secondly, capital related rules state that non-bank provider maintains capital at least at the level of $5 \%$ of the volume of outstanding loans. Removing tied sole trade creditor option. These and the rest of the rules were supposed to diminish negative phenomena that emerged over the last decade on the consumer credit market.

However, long before the regulation could be observed a downtrend of non-bank providers market share. Since the last economic crisis stroke the economy, the volume of consumer credit other than for house purchase provided by non-bank financial companies is decreasing from 216 million EUR in 2008 to less than 120 million EUR in 2016. These figures cover the members of the Czech Leasing and Financial Association. On the other hand, consumer credit volume of bank providers rose from 300 million EUR in 2008 to 420 million EUR in 2016 (Mejstrik and Dzmuran, 2018). However, non-bank provider consumer credit regarding companies in the Czech Leasing and Financial Association showed a year-on-year increase in the volume $1.8 \%$ and a slight decrease of number of contracts (Czech Leasing and Financial Association, 2018). In a similar manner, before the regulation took place one of the most cited negative effects of mis-providing of consumer credit other than for house purchase - natural entity insolvency and seizure of property, was declining.

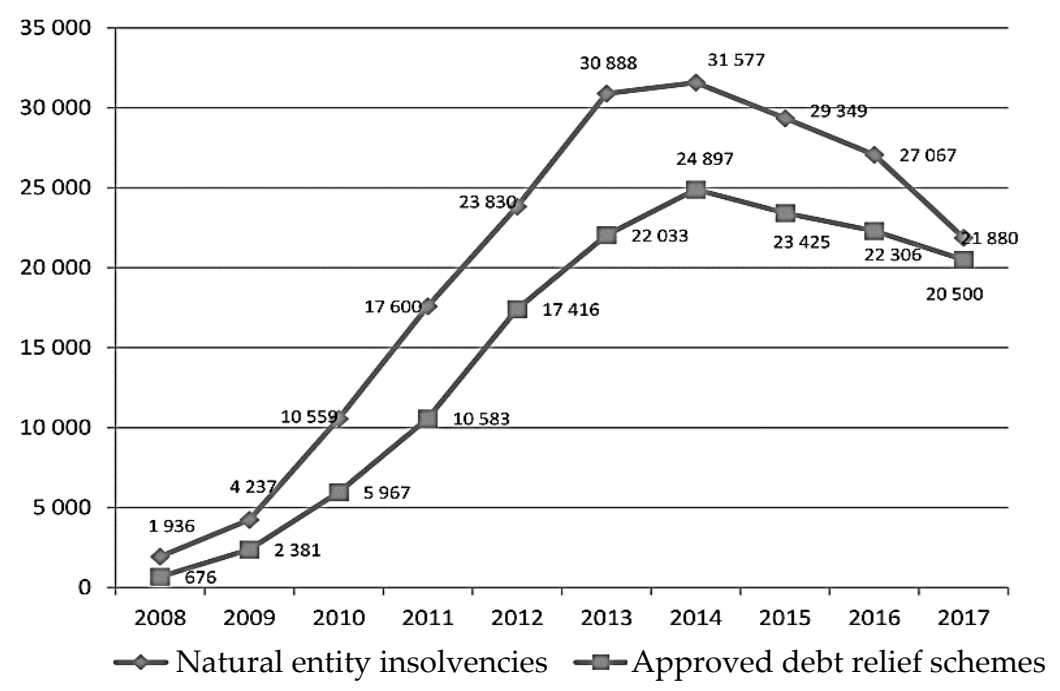

Figure 1. Number of natural entity solvencies and debt reliefs (Mejstrik and Dzmuran 2018). 
Nevertheless, the main impact of the regulation was a sharp decrease in consumer credit other than for house purchase providers and intermediaries. From an estimation of 55,000 providers and intermediaries (including tied sole traders) is now registered approximately 17,500 tied agents and intermediaries of tied consumer credit and 86 non-bank consumer credit providers (Czech National Bank, 2019; Mejstrik and Dzmuran, 2018) with a decreasing trend regarding the first group and stable trend regarding the latter one. Due to a capital requirement, a number of employees that have to declare professional qualification, etc. it took approximately one year before these providers were approved by the national regulator and registered.

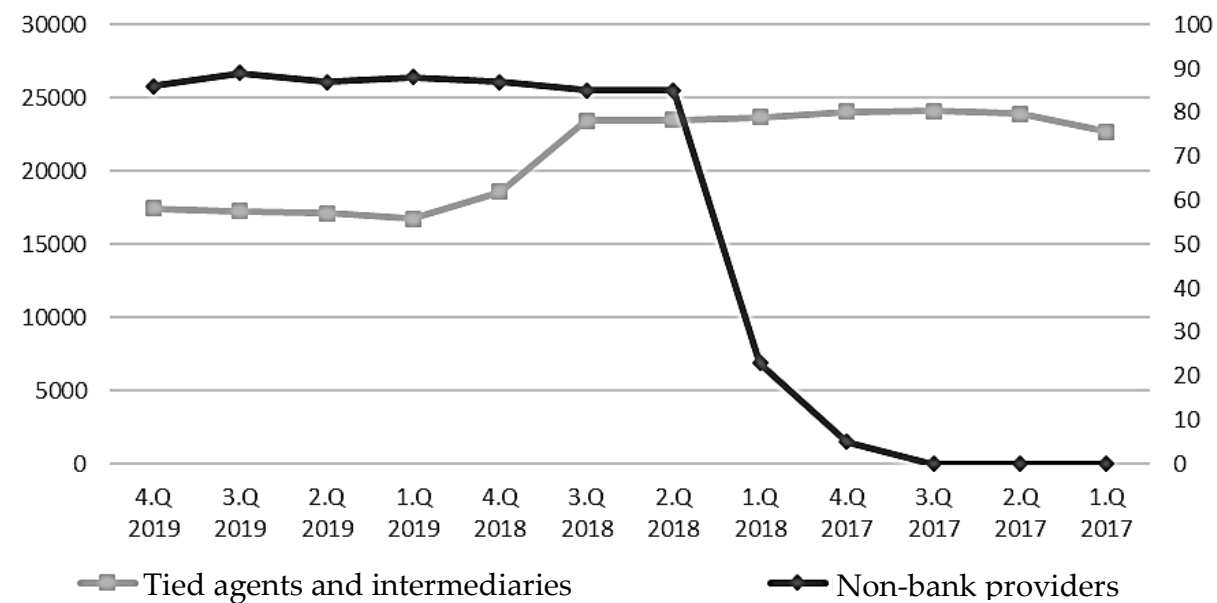

Figure 2. Number of registered agents and institutions (Czech National Bank 2019).

Although tied sole trader creditors cannot operate any more on the market of consumer credit, there is another option how to avoid regulation in form of a credit to entrepreneurs. An option of regulatory arbitrage is based on persuading a natural entity borrower to apply for the easiest form of sole trade with a very easy market entry. Then they will provide a credit but, in this case, it is not a consumer credit anymore and a borrower protection is completely lifted.

We did not address a question of whether the consumer protection is needed in this manner when the number of property seizures is diminishing. This question relates to not just an economic cycle, legal environment but also to financial literacy. Even though this issue is a part of obligatory education scheme e.g. study (Hedvicakova et al. 2017) showed that less than $50 \%$ of pupils in the sample did not reach a required score. If such results are present in a sample of those who had an opportunity to receive a financial literacy lessons, the situation among those who had not won't be better, on a contrary worse result can be expected. In such environment mainly, professional staff and creditworthiness assessment are beneficial for a society.

\subsection{Selected EU countries}

The majority of EU countries did not assign specific tasks of this nature to their national regulators, i.e. supervision over accredited persons professional qualification examination and an obligatory duty for consumer credit other than for house purchase providers or intermediators.

In Austria the Banking Act (Austrian Financial Market Authority, 2019) there are stated appropriate knowledge and skills in the areas concerned and they are to be refreshed and updated on a regular basis. It contains knowledge of credit products, of the legal provisions, comprehension of the procedures relating to the acquisition, credit products, ethical standards in business dealings, procedure of assessing the creditworthiness, financial and economic competence.

In the Bulgarian legislation, the Law on Consumer Credit (Bulgarian National Assembly, 2018) prescribes the requirements with regards to consumer credit agreements. Neither this law nor the applicable Bulgarian legislation contains professional qualification requirements for the distribution of consumer credit. 
As a part of MCD transposition, Croatian National Bank issues an outline of the process for training sales staff and a certificate of adequate knowledge and expertise. A credit institution is also obliged to prepare a training program and submit it to the Croatian national regulator no later than 31 January of each year. However, the transposition was not finished and so the European Commission has decided to refer Croatia to the Court of Justice of the EU for not enacting the MCD in their national legal system.

In German law, credit intermediaries are inter alia regulated by the Gewerbeordnung (Parliamentary Council of the Federal Republic of Germany, 2019), which states that credit intermediaries require an authorization. Such authorization can only be granted in cases where an examination passed before the Chamber of Industry and Commerce is presented as evidence that the applicant has the grounding in carrying out of credit intermediation activities, legal matters and customer services.

Greek national regulator (Bank of Greece) is assigned a number of tasks in relation to the certification process, including the eligibility assessment procedure and handling of the relevant documentation. The conditions for participating in the certification examinations, the examination syllabus, issues relating to the organization of the courses, the examinations procedure, the conditions and procedure for the renewal and withdrawal of the certificate. The fees are paid by the candidates. The examinations and relevant courses may be carried out by various entities, following an assessment of their capability by the national regulator stated in MCD transposition (Parliament and the president of the Hellenic Republic, 2016) and other national regulator related acts.

The central bank of Hungary duty is, concerning professional qualification, set by the Decree (Ministry of National economy, 2015) related to financial, insurance and capital markets service providers' agents. The national regulator supervises that the requirements for official examinations and examiners' activity comply with the decree. The financial education of financial, insurance and capital markets service providers' agents may be carried out by an official trainer firm registered with the Central bank of Hungary. The national regulator organizes the official exams and ensures the examiners.

In Ireland, the base for professional qualification is based on two Codes (Central Bank of Ireland, 2017a, 2017b). The aim is to ensure at least a minimum acceptable level of competence from individuals acting for and on behalf of regulated firms in the provision of advice and information and associated activities in connection with retail financial products. The standards apply to persons exercising a controlled function on a professional basis, the exercise of providing advice to consumers on retail financial products, arranging or offering to arrange retail financial products for consumers or exercise of a specified function. The Central Bank of Ireland does not take part in course design or examinations and credit intermediaries are not authorized by the Central Bank. A person who holds qualifications other than those recognized for the purposes of the MCC may seek an exemption from part of the recognized qualifications from the professional educational bodies providing those qualifications such as the Institute of Banking and The Insurance Institute.

In Netherland, every employee who gives advice with regard to financial products is required to have specific and standardized diplomas. In this case, the diplomas on Wet op het financieel toezicht basis (Queen of the Netherlands, 2017) and 'Wft Consumptief krediet' are mandatory. Aside from this, every financial service provider is obligated to have business procedures and processes with regard to the permanent professional competence of every single person in direct contact with customers, with regard to financial products. Even if these persons do not give advice.

In Poland, by (Polish sejm, 2019) a responsible institution is the Polish Financial Supervision Authority which exercises supervision of the banking and financial market in Poland and also takes part in the process of drafting legal acts related to financial market supervision. Consumer credit intermediaries are not subject to financial supervision. There are also no legal requirements for certain professional qualifications to provide such business. Consumer credit providers are fully responsible for the actions of their intermediaries.

Portuguese decree-law (Bank of Portugal, 2017) states that credit institutions will have to comply with regulatory requirements where, for instance, their employees hold a certificate of professional competence. Credit intermediaries must also conform to specific requirements of knowledge and 
competence. Under the Credit Intermediaries Law, the national regulator (Bank of Portugal) assesses compliance with the relevant requirements throughout the authorization procedure. Compliance with the requirement for staff to have an appropriate level of knowledge and competence can only be ascertained by a certificate of professional competence. According to decree-law (Bank of Portugal, 2017) and the Credit Intermediaries Law, certificates of professional competence may only be issued by entities certified by the Bank of Portugal. Under the relevant provisions, the Banco de Portugal is also responsible for monitoring those entities and may revoke its certification if it concludes that the conditions required have ceased to exist. The fulfillment of these tasks is financed by the national regulator.

Slovenian national regulator (Bank of Slovenia) is responsible for supervising compliance with the Consumer Credit Act of credit institutions, leasing companies and certain credit intermediaries. All these institutions are required to employ properly qualified staff as in provision and intermediation. Their national supervisor has the authority extended to supervise compliance with the provisions of the Consumer Credit Act that regulates education. These tasks of Bank of Slovenia are financed by the subjects of its supervision.

\section{Discussion and Conclusion}

Non-bank market performance might be connected to a type of Czech financial system. In categorization by a capital structure of (Allen and Gale, 2001) the Czech financial market is an example of B-market (Mejstrik et al., 2009) as almost all European continental countries. A different point of view provides (Walter, 2012) claiming that most of the countries have universal banking model and are dependent on it. Although conventional bank power slightly eroded on the consumer credit segment maybe because of the system non-bank financial companies did not disrupt a credit business as they did in typical M-system countries or Asia. There the share of assets held by banks and insurance companies has fallen thanks to funds and non-bank financial firms. Hence, traditional intermediaries have declined in importance even as the sector itself has been expanding (Allen and Santomero, 1997) and, in general, banks face increased competition from non-banks financial intermediaries (Melnik and Shy, 2015). There can an argued that the Czech financial market is less mature than M-system countries are, however, the French one, which is a typical B-system example, cannot be considered as less mature. Therefore, an increase of bank consumer credit share would be natural outcome of dominant bank position in B-system countries.

Another explanation dominant bank position in a consumer credit sector suggests a theory of bank and non-bank lending by (Thakor and Merton, 2018). Their banks have an endogenous advantage over non-bank lenders when it comes to being trusted to make good loans. Study (Begley and Srinivasan, 2019) provides empirical evidence that this trust advantage of banks matters to borrowers confirming that their unique access to low-cost deposit funding increases trust. However, e.g. model in the study (Boot and Thakor, 2000), later supported by findings (Degryse and Ongena, 2007), suggests that banks facing an increased non-bank competition react by loyalty strengthening counteractivity such as relationship loans.

There can be observed that in spite of an obligatory duty of MCD transposition an environment regarding professional qualification differs in both a regulatory approach at the level of a national regulator as well as on the level of requirements. Czech and Hungarian approaches are very close to public regulation with very little co-regulation. Central bank sets requirements, provides accreditation and supervises the professional examination process. The only difference is that in Czech Republic examination is not organized by the central bank. A similar system but with a wider range of authorized institutions for professional examining is adopted in Greece, Slovenia, and Portugal. Signs of co-regulation can be found in Croatia where credit institution is obliged to prepare a training program and submit it to Croatian national regulator for assessment. However, due to an uncompleted MCD transposition changes can be expected. In Germany and the Netherlands, the standards are based on minimum standards and trade code which are not provided or authorized by the central bank. Private regulation is also a case of Poland where credit providers are fully responsible for the actions of their intermediaries. 
Professional qualification, capital and other requirements lead to cleaning the market of the most obvious usurious and predatory form of consumer credits provision since it was mostly caused by tied sole trader creditors. However, although the regulation in the Czech Republic did clear the market of most doubtful non-bank financial companies and tied of sole trader creditors cannot participate on the market of consumer credit anymore, the problem was not treated completely. There is still one arbitrage option and this type of sole trader arbitrage is obviously detrimental and with strong possible negative consequences for consumers who decide to take this way to credit. However, the question is if it can be ever solved by a regulatory means since a decision to start a sole trader business cannot be limited when requisites are met. Still, time and other costs of such arbitrage efficiently prevent its mass misuse.

Acknowledgments: This paper was written with support of Specific Research Project "Investments within the Industry 4.0 concept" 2020 at Faculty of Informatics and Management of the University of Hradec Králové to the Department of Economics. We thank Martin Kral for his help with the paper preparation.

\section{References}

Allen Franklin, and Gale Douglas. (2001). Comparing financial systems. Cambridge: MIT Press.

Allen Franklin, and Santomero M. Anthony. (1997). The theory of financial intermediation. Journal of Banking Finance, 11-12, 1461-1485. https://doi.org/10.1016/S0378-4266(97)00032-0

Anagnostopoulos Ioannis. (2018). Fintech and regtech: Impact on regulators and banks. Journal of Economics and Business, 100, 7-25. https://doi.org/10.1016/j.jeconbus.2018.07.003

Austrian Financial Market Authority. (2019). Austrian Banking Act.

Baldwin Robert, Cave Martin, and Lodge Martin. (2010). The Oxford Handbook of Regulation. Oxford University Press. https://doi.org/10.1093/oxfordhb/9780199560219.001.0001

Bank of Portugal. (2017). Decree-Law 74-A/2017 Partially transposing Directive 2014/17 / EU on credit agreements for consumers for residential properties.

Boot W. A. Arnoud, and Thakor V. Anjan. (2000). Can Relationship Banking Survive Competition? The Journal of Finance, 2, 679-713. https://doi.org/10.1111/0022-1082.00223

Bulgarian National Assembly. (2018). Consumer Loan Act.

Cafaggi Fabrizio. (2009). Private regulation in European private law. EUI Working Papers. RSCAS 2009/31(July). San Domenico di $\quad$ Fiesole: $\quad$ EUI. Available online: https://cadmus.eui.eu/bitstream/handle/1814/12054/RSCAS_2009_31[rev].pdf?sequence=3 (accessed on 14 November 2019).

Central Bank of Ireland. (2017a). Minimum Competency Code. Available online: https://www.centralbank.ie/docs/default-source/regulation/how-we-regulate/authorisation/minimumcompetency/minimum-competency-code-2017.pdf?sfvrsn=4 (accessed on 14 December 2019).

Central Bank of Ireland. (2017b). Minimum Competency Regulations. Available online: https://www.centralbank.ie/docs/default-source/regulation/how-we-regulate/authorisation/minimumcompetency/minimum-competency-regulations-2017.pdf?sfvrsn=4 (accessed on 14 December 2019).

Czech Leasing and Financial Association. (2018). Report on the state of development of leasing, non-bank credit and factoring markets in the Czech Republic in 2018. Available online: https://www.clfa.cz/data/dokumenty/848-2018report.doc (accessed on 22 December 2019).

Czech National Bank. (2016a). Decree No. 381 of 16 November 2016, on applications, notifications and the submitting of statements pursuant to the Consumer Credit Act.

Czech National Bank. (2016b). Decree No. 384/2016 Coll. Of 23 November 2016 on professional qualifications for the distribution of consumer credit.

Czech National Bank. (2017). Supervisory Benchmark No. 1/2017 - The manner of generating tests when organising professional examinations pursuant to Act No. 257/2016 Coll., on Consumer Credit.

Czech National Bank. (2019). Register of regulated institutions and registered financial market entities. Available online: https://apl.cnb.cz/apljerrsdad/JERRS.WEB07.INTRO_PAGE?p_lang=en (accessed on 22 December 2019).

Da Silva T. Pedro, Leite Mauricio, Guse J. Carla, and Gollo Vanderlei. (2017). Financial and economic performance of major Brazilian credit cooperatives. Contaduría y Administración, 5, 1442-1459. https://doi.org/10.1016/j.cya.2017.05.006 
Degryse Hans, and Ongena Steven. (2007). The impact of competition on bank orientation. Journal of Financial Intermediation, 3, 399-424. https://doi.org/10.1016/j.jfi.2007.03.002

European Central Bank. (2015). Opinion of the European Central Bank of 9 December 2015 on consumer credit (CON/2015/54). Available online: https://www.ecb.europa.eu/ecb/legal/pdf/en_con_2015_54_f_sign.pdf (accessed on 22 December 2019).

European Parliament and Council. (2014). Directive 2014/17/EU of the European Parliament and of the Council of 4 February 2014 on credit agreements for consumers relating to residential immovable property. Official Journal of the European Union, L60, 34-75.

Hedvicakova Martina, Svobodova Libuse, Dittrichova Jaroslava, Kral Martin. (2017). Financial literacy and money management of the pupils in the Czech education system. Paper presented the conference Finance and performance of firms in science, education and practice. Zlin, Czech Republic, April 26-27, Zlin: Tomas Bata University, pp. 244-259. ISBN 978-80-7454-653-2.

Chamber of Deputies of the Czech Republic. (2014). Resolution of the Chamber of Deputies no. 367/2014. Available online: https://public.psp.cz/en/sqw/text/text2.sqw?idd=100579 (accessed on 6 January 2020).

Cherednychenko O. Olha. (2016). Cooperative or competitive? Private regulators and public supervisors in the post-crisis European financial services landscape. Policy and Society, 1, 103-114. https://doi.org/10.1016/j.polsoc.2015.12.005

Mejstrik, Michal, and Dzmuran Daniel. (2018). Navigátor bezpečného úvěru 2018. EEIP, plc. http://www.eeip.cz/wp-content/uploads/2019/04/190121_NBU_studie-final.pdf

Mejstrik Michal, Pecena Magda, and Teply Petr. (2009). Basic principles of banking. Prague: Charles University.

Melnik Arie, and Shy Oz. (2015). Exclusion, competition, and regulation in the retail loan market. Journal of Banking Finance, 52, 189-198. https://doi.org/10.1016/j.jbankfin.2014.08.019

Méndez-Pinedo M. Elvira. (2015). Iceland: Indexation of Credit and the Fairness Test in European Consumer Law. Journal of Consumer Policy,1, 61-92. https://doi.org/10.1007/s10603-014-9277-x

Ministry of National economy Hungary. (2015). Decree No. 40/2015. (XII. 30.) NGM of the Minister for National Economy on duties connected with official training and official examination for financial services intermediaries, insurance intermediaries and capital market traders.

Parliament of the Czech Republic. (2016). Act 257/2016 Coll. Of 14 July 2016, on Consumer Credit.

Parliamentary Council of the Federal Republic of Germany. (2019). Commercial Code.

Parliament and the president of the Hellenic Republic. (2016). Law 4438/2016 Harmonization of legislation with the Directive European Parliament 2014/17 / EU and of the Council of 4 February 2014 on consumer credit agreements for residential real estate and amending Directives 2008 / 48 / EC and 2013/36 / EU and Regulation (EU) No. 1093/2010, and other provisions of competence of the Ministry of Finance.

Polish sejm. (2019). Act on financial market supervision.

Queen of the Netherlands. (2017). Financial Supervision Act.

Rona-Tas Akos, Guseva Alya. (2013). Information and consumer credit in Central and Eastern Europe. Journal of Comparative Economics, 2, 420-435. https://doi.org/10.1016/j.jce.2013.03.012

Stringham E. Peter. (2015). Private Governance: Creating Order in Economic and Social Life. Oxford: Oxford University Press. https://doi.org/10.1093/acprof:oso/9780199365166.001.0001

Thakor Richard, and Merton Robert. (2018). Trust in Lending. NBER working paper series. No. 24778(June). Cambridge: National Bureau of Economic Research. Available online: https://www.nber.org/papers/w24778.pdf (accessed on 6 January 2020).

Walter, I. (2012). Universal banking and financial architecture. The Quarterly Review of Economics and Finance, 2, 114-122. https://doi.org/10.1016/j.qref.2011.12.007 